\title{
Glucocorticoid therapy in assisted reproduction
}

\author{
Yong Jin Kim \\ Department of Obstetrics and Gynecology, Korea University College of Medicine, Seoul, Korea
}

As glucocorticoids are well-known as important regulators of stress and the immune system, their function and clinical use have elicited substantial interest in the field of reproduction. In particular, the effect of glucocorticoid therapy on endometrial receptivity during assisted reproduction, including in vitro fertilization (IVF) cycles, has led to a great deal of interest and controversy. However, previous studies have not been able to provide consistent and reliable evidence due to their small, non-controlled designs and use of different criteria. Considering the potential risk of exposure to glucocorticoids for mothers and fetuses in early pregnancy, the use of glucocorticoids in IVF cycles should be carefully evaluated, including the balance between risk and benefit. To date, there is no conclusive evidence that the use of glucocorticoids improves the pregnancy rate in IVF cycles with unselected subjects, and a further investigation should be considered with a proper study design.

Keywords: In vitro fertilization; Glucocorticoids; Pregnancy rate; Receptivity

\section{Introduction}

Achieving pregnancy with assisted reproductive technology can be affected by multifactorial causes. To date, numerous studies have documented ways of improving the outcomes of in vitro fertilization (IVF), the most important assisted reproductive technique clinically used to manage infertility. These efforts include optimizing IVF procedures in terms of ovarian stimulation [1], oocyte retrieval [2], fertilization [3], and the embryo culture system [4]. However, the current technique as relates to the steps from embryo transfer to implantation - the final hurdle to pregnancy —remains difficult to consider as having been optimized [5]. The uterine endometrium is the last barrier to overcome in order to make further progress in assisted reproductive technology [6].

Endometrial receptivity can be defined as the capacity for endometrial maturation, during which the trophectoderm of the blastocyst can attach to the endometrial epithelial cells and subsequently

Received: July 1, 2021 - Revised: July 30, 2021 · Accepted: August 2, 2021 Corresponding author: Yong Jin Kim

Department of Obstetrics and Gynecology, Korea University Guro Hospital, 148 Gurodong-ro, Guro-gu, Seoul 08308, Korea

Tel: +82-2-2626-3033 Fax: +82-2-838-1560 E-mail: zinigo@Korea.ac.kr

This is an Open Access article distributed under the terms of the Creative Commons Attribution Non-Commercial License (http://creativecommons.org/licenses/by-nc/4.0/) which permits unrestricted non-commercial use, distribution, and reproduction in any medium, provided the original work is properly cited. proceed to invade the endometrial stroma and vasculature [7]. It provides the embryo with the opportunity to attach, invade, and develop in the maternal uterine environment, within the exceptional 3to 5-day period known as "the window of implantation." Various strategies for improving endometrial receptivity have been studied, including identifying biomarkers to schedule embryo transfer [8,9], endometrial scratching [10], applying medication or materials to the uterine endometrium [11,12], and even a freeze-all strategy after IVF with controlled ovarian stimulation [13]. However, the strategy that induces optimal endometrial receptivity has not yet been confirmed clinically.

Previous studies have reported that the immune system plays a central role in endometrial receptivity, with resident immune cells modulating the decidual response, epithelial attachment of the embryo, trophoblast invasion, vascular adaptation, and immune tolerance [14-16]. Based on this hypothesis, glucocorticoids have been proposed as a way to improve the embryo implantation rate after IVF and to protect against miscarriage, when administered during embryo implantation through the early placentation phase $[17,18]$. However, no well-designed clinical studies have offered acceptable conclusions regarding the indications, effectiveness, and safety of adjuvant corticosteroid therapy in IVF cycles. This review aimed to evaluate previous studies on glucocorticoid therapy during IVF cycles and to elucidate weak points to address in future research. 


\section{Glucocorticoids and reproduction}

Glucocorticoids are essential steroid hormones that regulate diverse cellular functions and are indispensable for maintaining normal physiology by inducing the capacity to respond appropriately to stress through the regulation of metabolic activity, behavior, and even reproduction. Glucocorticoids are synthesized and released by the adrenal cortex under the regulation of the hypothalamus-pituitary-adrenal (HPA) axis, in a pulsatile pattern showing both circadian and ultradian rhythms. Corticotropin-releasing hormone $(\mathrm{CRH})$ and arginine vasopressin are secreted from the parvicellular neurons of the hypothalamus into the pituitary portal circulation, thereby stimulating adrenocorticotropic hormone (ACTH) release from the anterior pituitary gland [19]. ACTH stimulates the adrenal gland to induce steroidogenesis and the production of glucocorticoids. Increased glucocorticoid levels, in contrast, inhibit CRH expression and its secretion, as well as ACTH output by endocrine feedback loops [20]. This rhythmic regulation of glucocorticoid levels is critical for the maintenance of physiological homeostasis and adjustment to acute stress exposure by transiently inducing HPA activity. However, this regulation is not restricted to the HPA axis; instead, it also involves adjustments at the systemic level. The enzyme 11 $\beta$-hydroxysteroid dehydrogenase type 1 (11ß-HSD1) produces cortisol by the enzymatic reduction of cortisone, and the reverse reaction is catalyzed by $11 \beta$-hydroxysteroid dehydrogenase type 2 (11ß-HSD2) [21]. Additionally, the glucocorticoid receptor (GR) mediates glucocorticoid activity in a diverse manner, ranging from stimulation to suppression in a cell-specific manner [22-24]. The GR is a member of the nuclear receptor superfamily of ligand-dependent transcription factors and has a modular structure composed of three distinct functional domains [25]. Between the DNA-binding domain and the ligand-binding domain lies a flexible hinge region that provides structural flexibility for genomic interactions and contains a nuclear localization signal [26].

Increased glucocorticoid levels, resulting from either endogenous or exogenous processes, cause various types of reproductive dysfunction via effects in the hypothalamus and pituitary gland within the HPA axis [27]. Recent animal studies suggested that glucocorticoids disturb the hypothalamus-pituitary-ovary axis by direct inhibition of gonadotropin-releasing hormone $(\mathrm{GnRH})$ secretion from the hypothalamus and the synthesis and the release of gonadotropins from the pituitary by suppressing kisspeptin (KISS1) [28,29] and inducing gonadotropin-inhibitory hormone [30,31].

In addition to the effects in the upper neuro-endocrine area, glucocorticoids are known to impact ovarian cyclic physiology and steroidogenesis directly by regulating the functions of granulosa cells, oocytes, cumulus cells, and luteal cells [29,32]. Increased glucocorti- coid levels impair the developmental competence of oocytes by triggering apoptosis of granulosa cells [33]. Glucocorticoids differentially induce and repress steroidogenesis in the ovary according to their dose or the stage of follicular development $[32,34,35]$. The complexity of the relationship between glucocorticoids and ovarian function remains to be elucidated because most previous studies have conducted exposure experiments instead of investigating physiologic functional changes in the ovary.

Early exposure to glucocorticoids blocks estrogen-induced uterine growth, thereby reducing the quantitative capacity of implantation $[36,37]$. In the endometrium, GR is expressed in stromal, endothelial, and uterine natural killer (uNK) cells [38]. Given that glucocorticoids inhibit angiogenesis [39], reports that the endometrial expression of $11 \beta$-HSD1 and GR mRNA is upregulated at menstruation [40], and that the activity of glucocorticoids decreases in response to enhanced $11 \beta$-HSD2 levels in the endometrium of women with heavy menstrual bleeding [41], implicate the role of glucocorticoids in the uterine menstrual cycle.

\section{Glucocorticoids and immune modulation}

For endometrial receptivity to the semi-allogenic fetus and maintenance of successful pregnancy, various immune cells are recruited and tuned in the microenvironment of the endometrial compartment [42]. Previous studies have revealed the roles of the four main immune cell lineages: uNK cells, dendritic cells (DCs), macrophages, and T-cells. First, uNK cells are known to be important actors in decidual blood vessel modification during the implantation period [43], as well as in uterine arterial modification and optimal placentation for the development of offspring in early pregnancy $[44,45]$. Interacting with uNK cells, DCs have been reported to control the adaptive immune compartment and to drive the generation of inducible regulatory $T$ cells to suppress inflammation and mediate immune tolerance of fetal antigens $[46,47]$. A previous study showed that depletion of uterine DCs resulted in aberrant decidual vascularization and placentation, leading to impaired implantation [48]. The M2 type of macrophages is required for embryo implantation, ovarian progesterone synthesis, and fetal development $[49,50]$. It was reported that M2 macrophages inhibit inflammation and contribute to immunosuppressive function by secreting anti-inflammatory cytokines [51,52]. In interacting with uNK cells and DCs for optimal implantation and successful pregnancy, regulatory $T$ cells regulate vascular adaptation and placental development $[53,54]$. Some clinical studies suggested evidence that alterations of these immune cells were linked to infertility [55-58]. These immune cells and secreted mediators build on the cyclic immune changes that accompany hormonal fluctuations over the course of every menstrual cycle, particularly af- 
ter boosting embryo attachment and trophoblast invasion.

Glucocorticoids could act as potent players in this process due to their potent anti-inflammatory and immunosuppressant actions. Some studies have revealed the effect of exogenous glucocorticoid exposure on these immune cells in the receptivity process $[38,59]$. uNK cell-mediated cytotoxicity is sensitive to exogenous glucocorticoids by regulation via GR [38,60], and the number of uNK cells in the mid-luteal endometrium decreases [61]. The function of DCs is reported to change in response to glucocorticoids, in terms of their phenotype, maturation, and antigen-presentation [62]. Corticosteroids impair the ability of DCs to activate $T$ cells and shift the balance from cellular (Th1) immunity to humoral (Th2) immunity, and regulatory $T$ cells are induced $[63,64]$. Corticosteroids shift the macrophage phenotype from pro-inflammatory (M1) to anti-inflammatory (M2), promote phagocytosis, inhibit major histocompatibility complex II expression, block the synthesis of cytokines, prostaglandins, and leukotrienes, and depress tumoricidal and microbicidal activity [63]. Glucocorticoids seem to increase the activity of regulatory $T$ cells and decrease the cytotoxicity of NK cells simultaneously. However, recent studies on immune regulation have suggested that these regulatory activities could be individualized for each respective cell rather than being regulated in the manner of general suppression by glucocorticoids $[65,66]$.

\section{Glucocorticoids and the ovarian response}

Some previous studies implied that glucocorticoids have positive effects on the ovarian response to stimulation. One study showed that dexamethasone may influence follicular development and oocyte maturation directly, via 11 $\beta$-HSD1 in granulosa cells [67], or indirectly, by increasing serum growth hormone and intrafollicular IGF-1 levels $[68,69]$. The activity of $11 \beta-H S D$ in ovarian follicular fluid has even been suggested as a predictive marker for IVF outcomes [70]. However, there have been few studies investigating whether glucocorticoid treatment enhances the ovarian response in IVF cycles, and the positive results showing an improved pregnancy rate were mainly reported in old preliminary studies [71]. A previous randomized controlled trial (RCT) showed a lower cycle cancellation rate in IVF cycles of normal responders using oral dexamethasone, but without differences in fertilization, implantation, and pregnancy rates [72]. A recent study suggested that low-dose oral dexamethasone in women with high progesterone levels in the early proliferative phase sensitized the ovary to gonadotropin stimulation, leading to the secretion of less progesterone, and the dexamethasone group showed a higher cumulative live birth rate than the control group [73]. Consequently, to date, the clinical evidence for using glucocorticoids to enhance the ovarian response is limited.

Table 1. Meta-analysis of glucocorticoid therapy in IVF cycles

\begin{tabular}{|c|c|c|c|c|}
\hline Study & Journal (year) & Included RCT (n, criteria) & Main outcome & Subgroup analysis \\
\hline \multirow[t]{2}{*}{ Boomsma et al. [74] } & $\begin{array}{l}\text { Cochrane Database Syst Rev } \\
\text { (2007) }\end{array}$ & 13 RCTs (1,759 couples, none) & $\begin{array}{l}\text { LBR (OR, 1.21; 95\% Cl, 0.67-2.19; } \\
\text { NS; } 3 \text { RCTs) }\end{array}$ & $\begin{array}{c}\text { PR per couple in IVF (OR, 1.5; } 95 \% \\
\mathrm{Cl}, 1.05-2.13 ; p=0.02 ; 6 \mathrm{RCTs})\end{array}$ \\
\hline & & & $\begin{array}{l}\text { OPR (OR, 1.15; 95\% Cl, 0.76-1.75; } \\
\text { NS; } 3 \text { RCTs) }\end{array}$ & \\
\hline Boomsma et al. [74] & $\begin{array}{l}\text { Cochrane Database Syst Rev } \\
\text { (2012) }\end{array}$ & 14 RCTs ( 1,879 couples, none) & $\begin{array}{l}\text { LBR (OR, 1.21; 95\% Cl, 0.67-2.19; } \\
\text { NS; } 3 \text { RCTs) }\end{array}$ & $\begin{array}{l}\text { PR per couple in IVF (OR, } 1.5 ; 95 \% \\
\mathrm{Cl}, 1.05-2.13 ; p=0.02 ; 6 \mathrm{RCTs})\end{array}$ \\
\hline \multirow[t]{2}{*}{ Dan et al. [75] } & Am J Reprod Immunol (2015) & $\begin{array}{l}5 \text { RCTs (828 couples, unex- } \\
\text { plained recurrent miscarriage) }\end{array}$ & $\begin{array}{l}\mathrm{LBR}(\mathrm{OR}, 1.58 ; 95 \% \mathrm{Cl}, 1.23-2.02 ; \\
\quad p=0.0003 ; 2 \mathrm{RCTs})\end{array}$ & $\begin{array}{l}\mathrm{MR}(\mathrm{OR}, 0.5 ; 95 \% \mathrm{Cl}, 0.31-0.81 \\
\quad p=0.005 ; 2 \mathrm{RCTs})\end{array}$ \\
\hline & & & $\begin{array}{l}\text { OPR (OR, 7.63; } 95 \% \mathrm{Cl}, 3.71-15.69 \\
\quad p<0.00001 ; 1 \mathrm{RCTs})\end{array}$ & \\
\hline Kalampokas et al. [76] & $\begin{array}{l}\text { Cochrane Database Syst Rev } \\
\text { (2017) }\end{array}$ & 4 RCTs (416 couples, none) & $\begin{array}{l}\text { LBR (OR, 1.08; 95\% Cl, 0.45-2.58; } \\
\text { NS; } 2 \text { RCTs) }\end{array}$ & \\
\hline Achilli et al. [77] & Fertil Steril (2018) & $\begin{array}{l}2 \text { RCTs (202 couples, recurrent } \\
\text { pregnancy loss) }\end{array}$ & $\begin{array}{l}\text { OPR (OR, 1.12; 95\% Cl, 0.75-1.67; } \\
\text { NS; } 2 \text { RCTs) }\end{array}$ & \\
\hline \multirow[t]{2}{*}{ Zhou et al. [78] } & Medicine (2021) & $\begin{array}{l}3 \text { RCTs ( } 237 \text { couples, anti-thyroid } \\
\text { antibody positive) }\end{array}$ & $\begin{array}{l}\mathrm{LBR}(\mathrm{OR}, 3.19 ; 95 \% \mathrm{Cl}, 1.13-9.04 ; \\
\quad p=0.03 ; 2 \mathrm{RCTs})\end{array}$ & $\begin{array}{l}\text { MR (OR, 0.62; 95\% Cl, 0.09-4.32; } \\
\text { NS; } 3 \text { RCTs) }\end{array}$ \\
\hline & & & $\begin{array}{l}\mathrm{OPR}(\mathrm{OR}, 4.63 ; 95 \% \mathrm{Cl}, 2.23-9.58 \\
\quad p<0.0001 ; 3 \mathrm{RCTs})\end{array}$ & \\
\hline
\end{tabular}

IVF, in vitro fertilization; $\mathrm{RCT}$, randomized controlled trial; LBR, live birth rate; $\mathrm{OR}$, odds ratio; $\mathrm{Cl}$, confidence interval; NS, not significant; $\mathrm{PR}$, pregnancy rate; $\mathrm{OPR}$, ongoing pregnancy rate; $\mathrm{MR}$, miscarriage rate. 


\section{Glucocorticoids and embryo implantation}

Historically, early experiences of using glucocorticoids in the IVF cycle were for women with positive autoantibodies. With or without low-dose aspirin, some studies reported that glucocorticoid therapy in the peri-embryo implantation period improved the pregnancy rate after IVF in women with positive anti-nuclear antibodies, anti-cardiolipin antibodies, anti-thyroid antibodies, or lupus anticoagulant $[17,79,80]$. Furthermore, a few studies suggested that glucocorticoid therapy could enhance the IVF pregnancy rate for women without positive autoantibodies [81] and even with unexplained repeated pregnancy loss $[82,83]$. In contrast to these positive studies, other studies reported that glucocorticoid therapy showed no additional benefit in implantation and pregnancy rates regardless of the dose [84-88]. These discrepant findings concerning the effectiveness of glucocorticoid therapy could be due to inconsistencies in the criteria for recruiting subjects and protocols, including the drugs utilized, dose, and schedule.

Six meta-analyses have been published regarding the effects of glucocorticoids on IVF outcomes [74-78]. The main outcomes are summarized in Table 1. In 2007, the first was published by Boomsma et al. [74], who included 13 studies and found that glucocorticoid therapy led to no significant improvement in the live birth rate (odds ratio $[\mathrm{OR}], 1.21 ; 95 \%$ confidence interval $[\mathrm{Cl}], 0.67-2.19)$ or the pregnancy rate $(\mathrm{OR}, 1.15 ; 95 \% \mathrm{Cl}, 0.76-1.76)$. In a subgroup analysis including only fresh IVF cycles, they suggested that the pregnancy rate was significantly enhanced (OR, 1.50; 95\% Cl, 1.05-2.13) in the glucocorticoid treatment groups. In 2012, they reported an updated meta-analysis including 14 studies that showed similar results [74]. Dan et al. [75] reported that prednisolone therapy during IVF cycles improved pregnancy outcomes in women with idiopathic recurrent miscarriage (live birth rate: risk ratio [RR], 1.58; 95\% Cl, 1.23-2.02; successful pregnancy outcome: RR, 7.63; 95\% Cl, 3.71-15.69; miscarriage rate: $\mathrm{RR}, 0.42 ; 95 \% \mathrm{Cl}, 0.28-0.61)$, in five RCTs. Significant outcomes were not found in a subgroup analysis only including intracytoplasmic sperm injection (ICSI) cycles in their study. In a meta-analysis with four RCTs, Kalampokas et al. [76] reported that there was no conclusive evidence of a difference in the clinical pregnancy rate (OR, 1.69; 95\% Cl, 0.98-2.90) between glucocorticoid supplementation during ovarian stimulation for IVF or ICSI and the control group. A meta-analysis about the effects of various immunotherapies in IVF cycles for women with recurrent pregnancy loss revealed that prednisolone therapy also showed no significant favorable differences in the pregnancy rate $(\mathrm{OR}, 1.02 ; 95 \% \mathrm{Cl}, 0.65-1.58)$ in 2 RCTs [77]. Recently, a meta-analysis of the benefits of glucocorticoid treatment in infertile women with thyroid autoimmune disease during IVF cycles suggested that glucocorticoid therapy showed satisfactory effects on improving the clinical pregnancy (OR, 4.63; 95\% Cl, 2.23-9.58) and live birth rates $(\mathrm{OR}, 3.19 ; 95 \% \mathrm{Cl}, 1.13-9.04)$ in three RCTs [78]. Nonetheless, the efficacy of glucocorticoid therapy in IVF cycles remains to be elucidated, due to the limited number of included studies, as the authors pointed out in their meta-analysis.

\section{Glucocorticoids and potential risk}

Most glucocorticoids belong to category $C$ or $D$ according to the United States Food and Drug Administration. This indicates that animal reproduction studies without adequate and well-controlled human data or human data from investigational or marketing experience have shown adverse effects on the fetus, but the potential benefits may warrant use of the drug in pregnant women despite the potential risks. Thus, it is important to consider the benefits and risks of glucocorticoid therapy in IVF cycles, which potentially affect the early pregnancy period. Some animal studies have claimed that exposure to glucocorticoids causes fetal growth retardation, cardiovascular, metabolic, and neuroendocrine disorders, and teratogenic effects $[89,90]$. Some limited human studies have shown that the use of glucocorticoids spanning the first trimester might be correlated with increases in miscarriage, preterm births, gestational hypertension, and diabetes [91,92]. Although glucocorticoids do not represent a major teratogenic risk in humans, some studies have revealed a possible causal association between cleft lip and palate and the use of corticosteroids during the peri-implantation phase [91,93,94]. Unlike cases in which glucocorticoids must be used due to underlying disease, deliberate risk/benefit analyses should be carried out in cases without preexisting indications for the use of glucocorticoids in IVF cycles.

\section{Conclusions}

Glucocorticoids are important regulators of physiologic homeostasis, immune activation, and responses to inflammatory events; therefore, they also play a relevant role in reproduction. The response of endometrial and decidual immune cells required for normal implantation presents a spectrum from normal variation to the status of impaired implantation and affected placentation by corticosteroids. Previous studies have attempted to reveal the effect of glucocorticoid therapy in IVF cycles, showing some possible benefits in patients with autoimmune disease or idiopathic recurrent pregnancy loss. However, most reports were based on small, non-controlled designs with inconsistent criteria, and their conclusions cannot be interpreted as reflecting a scientific consensus. Taken together with the potential maternal and fetal risk, the use of glucocorticoids in IVF cycles should be cautious, and the balance between the risks and ben- 
efits should be considered. To elucidate solid indications and a clinical protocol to improve IVF outcomes by using glucocorticoids, further investigation should be considered in properly designed studies.

\section{Conflict of interest}

No potential conflict of interest relevant to this article was reported.

\section{ORCID}

Yong Jin Kim

https://orcid.org/0000-0001-8684-2126

\section{References}

1. Kolibianakis EM, Kalogeropoulou L, Griesinger G, Papanikolaou EG, Papadimas J, Bontis J, et al. Among patients treated with FSH and $\mathrm{GnRH}$ analogues for in vitro fertilization, is the addition of recombinant LH associated with the probability of live birth?: a systematic review and meta-analysis. Hum Reprod Update 2007;13: 445-52.

2. Benaglia L, Busnelli A, Biancardi R, Vegetti W, Reschini M, Vercellini $\mathrm{P}$, et al. Oocyte retrieval difficulties in women with ovarian endometriomas. Reprod Biomed Online 2018;37:77-84.

3. Zheng D, Zeng L, Yang R, Lian Y, Zhu YM, Liang X, et al. Intracytoplasmic sperm injection (ICSI) versus conventional in vitro fertilisation (IVF) in couples with non-severe male infertility (NSMI-ICSI): protocol for a multicentre randomised controlled trial. BMJ Open 2019;9:e030366.

4. Chronopoulou E, Harper JC. IVF culture media: past, present and future. Hum Reprod Update 2015;21:39-55.

5. Bashiri A, Halper KI, Orvieto R. Recurrent implantation failure: update overview on etiology, diagnosis, treatment and future directions. Reprod Biol Endocrinol 2018;16:121.

6. Edwards RG. Human implantation: the last barrier in assisted reproduction technologies? Reprod Biomed Online 2006;13:887904.

7. Lessey BA, Young SL. Structure, function, and evaluation of the female reproductive tract. In: Strauss JF, Barbieri RL. editors. Yen and Jaffe's reproductive endocrinology. Philadelphia: Elsevier; 2019. p. 206-47.

8. Hernandez-Vargas P, Munoz M, Dominguez F. Identifying biomarkers for predicting successful embryo implantation: applying single to multi-OMICs to improve reproductive outcomes. Hum Reprod Update 2020;26:264-301.

9. Drakopoulos P, Racca A, Errazuriz J, De Vos M, Tournaye H, Blockeel $\mathrm{C}$, et al. The role of progesterone elevation in IVF. Reprod Biol
2019;19:1-5.

10. Olesen MS, Hauge B, Ohrt L, Olesen TN, Roskaer J, Baek V, et al. Therapeutic endometrial scratching and implantation after in vitro fertilization: a multicenter randomized controlled trial. Fertil Steril 2019;112:1015-21.

11. Kim H, Shin JE, Koo HS, Kwon H, Choi DH, Kim JH. Effect of autologous platelet-rich plasma treatment on refractory thin endometrium during the frozen embryo transfer cycle: a pilot study. Front Endocrinol (Lausanne) 2019;10:61.

12. Zhang T, Chen X, Wang CC, Li TC, Kwak-Kim J. Intrauterine infusion of human chorionic gonadotropin before embryo transfer in IVF/ ET cycle: the critical review. Am J Reprod Immunol 2019;81: e13077.

13. Bourdon M, Maignien C, Pocate-Cheriet K, Plu Bureau G, Marcellin $\mathrm{L}$, Patrat $\mathrm{C}$, et al. The freeze-all strategy after IVF: which indications? Reprod Biomed Online 2021;42:529-45.

14. van Mourik MS, Macklon NS, Heijnen CJ. Embryonic implantation: cytokines, adhesion molecules, and immune cells in establishing an implantation environment. J Leukoc Biol 2009;85:4-19.

15. Redman CW, Sargent IL. Immunology of pre-eclampsia. Am J Reprod Immunol 2010;63:534-43.

16. Robertson SA, Jin M, Yu D, Moldenhauer LM, Davies MJ, Hull ML, et al. Corticosteroid therapy in assisted reproduction: immune suppression is a faulty premise. Hum Reprod 2016;31:2164-73.

17. Hasegawa I, Yamanoto Y, Suzuki M, Murakawa H, Kurabayashi T, Takakuwa K, et al. Prednisolone plus low-dose aspirin improves the implantation rate in women with autoimmune conditions who are undergoing in vitro fertilization. Fertil Steril 1998;70: 1044-8.

18. Krigstein M, Sacks G. Prednisolone for repeated implantation failure associated with high natural killer cell levels. J Obstet Gynaecol 2012;32:518-9.

19. Whirledge S, Cidlowski JA. Glucocorticoids and reproduction: traffic control on the road to reproduction. Trends Endocrinol Metab 2017:28:399-415.

20. Aguilera G. Regulation of pituitary ACTH secretion during chronic stress. Front Neuroendocrinol 1994;15:321-50.

21. Edwards CR, Benediktsson R, Lindsay RS, Seckl JR. 11 beta-Hydroxysteroid dehydrogenases: key enzymes in determining tissue-specific glucocorticoid effects. Steroids 1996;61:263-9.

22. Lu NZ, Collins JB, Grissom SF, Cidlowski JA. Selective regulation of bone cell apoptosis by translational isoforms of the glucocorticoid receptor. Mol Cell Biol 2007;27:7143-60.

23. Nehme A, Lobenhofer EK, Stamer WD, Edelman JL. Glucocorticoids with different chemical structures but similar glucocorticoid receptor potency regulate subsets of common and unique genes in human trabecular meshwork cells. BMC Med Genomics 2009; 
2:58.

24. Gross KL, Oakley RH, Scoltock AB, Jewell CM, Cidlowski JA. Glucocorticoid receptor alpha isoform-selective regulation of antiapoptotic genes in osteosarcoma cells: a new mechanism for glucocorticoid resistance. Mol Endocrinol 2011;25:1087-99.

25. Joseph DN, Whirledge S. Stress and the HPA axis: balancing homeostasis and fertility. Int J Mol Sci 2017;18:2224.

26. Kadmiel M, Cidlowski JA. Glucocorticoid receptor signaling in health and disease. Trends Pharmacol Sci 2013;34:518-30.

27. Whirledge S, Cidlowski JA. A role for glucocorticoids in stress-impaired reproduction: beyond the hypothalamus and pituitary. Endocrinology 2013;154:4450-68.

28. Takumi K, lijima N, Higo S, Ozawa H. Immunohistochemical analysis of the colocalization of corticotropin-releasing hormone receptor and glucocorticoid receptor in kisspeptin neurons in the hypothalamus of female rats. Neurosci Lett 2012;531:40-5.

29. Luo E, Stephens SB, Chaing S, Munaganuru N, Kauffman AS, Breen KM. Corticosterone blocks ovarian cyclicity and the LH surge via decreased kisspeptin neuron activation in female mice. Endocrinology 2016;157:1187-99.

30. Clarke IJ, Bartolini D, Conductier G, Henry BA. Stress increases gonadotropin inhibitory hormone cell activity and input to $\mathrm{GnRH}$ cells in ewes. Endocrinology 2016;157:4339-50.

31. Kirby ED, Geraghty AC, Ubuka T, Bentley GE, Kaufer D. Stress increases putative gonadotropin inhibitory hormone and decreases luteinizing hormone in male rats. Proc Natl Acad Sci U S A 2009;106:11324-9.

32. Yuan XH, Yang BQ, Hu Y, Fan YY, Zhang LX, Zhou JC, et al. Dexamethasone altered steroidogenesis and changed redox status of granulosa cells. Endocrine 2014;47:639-47.

33. Yuan HJ, Han X, He N, Wang GL, Gong S, Lin J, et al. Glucocorticoids impair oocyte developmental potential by triggering apoptosis of ovarian cells via activating the Fas system. Sci Rep 2016;6: 24036 .

34. Huang TJ, Shirley Li P. Dexamethasone inhibits luteinizing hormone-induced synthesis of steroidogenic acute regulatory protein in cultured rat preovulatory follicles. Biol Reprod 2001; 64:163-70.

35. Michael AE, Pester LA, Curtis P, Shaw RW, Edwards CR, Cooke BA. Direct inhibition of ovarian steroidogenesis by cortisol and the modulatory role of 11 beta-hydroxysteroid dehydrogenase. Clin Endocrinol (Oxf) 1993;38:641-4.

36. Rhen T, Grissom S, Afshari C, Cidlowski JA. Dexamethasone blocks the rapid biological effects of 17beta-estradiol in the rat uterus without antagonizing its global genomic actions. FASEB J 2003; 17:1849-70.

37. Johnson DC, Dey SK. Role of histamine in implantation: dexa- methasone inhibits estradiol-induced implantation in the rat. Biol Reprod 1980;22:1136-41.

38. Henderson TA, Saunders PT, Moffett-King A, Groome NP, Critchley HO. Steroid receptor expression in uterine natural killer cells. J Clin Endocrinol Metab 2003;88:440-9.

39. Logie JJ, Ali S, Marshall KM, Heck MM, Walker BR, Hadoke PW. Glucocorticoid-mediated inhibition of angiogenic changes in human endothelial cells is not caused by reductions in cell proliferation or migration. PLoS One 2010;5:e14476.

40. McDonald SE, Henderson TA, Gomez-Sanchez CE, Critchley HO, Mason Jl. 11Beta-hydroxysteroid dehydrogenases in human endometrium. Mol Cell Endocrinol 2006;248:72-8.

41. Rae M, Mohamad A, Price D, Hadoke PW, Walker BR, Mason Jl, et al. Cortisol inactivation by 11 beta-hydroxysteroid dehydrogenase-2 may enhance endometrial angiogenesis via reduced thrombospondin-1 in heavy menstruation. J Clin Endocrinol Metab 2009;94:1443-50.

42. Figueiredo AS, Schumacher A. The T helper type 17/regulatory T cell paradigm in pregnancy. Immunology 2016;148:13-21.

43. Madeja Z, Yadi H, Apps R, Boulenouar S, Roper SJ, Gardner L, et al. Paternal MHC expression on mouse trophoblast affects uterine vascularization and fetal growth. Proc Natl Acad Sci U S A 2011; 108:4012-7.

44. Lima PD, Zhang J, Dunk C, Lye SJ, Croy BA. Leukocyte driven-decidual angiogenesis in early pregnancy. Cell Mol Immunol 2014;11:522-37.

45. Moffett A, Colucci F. Uterine NK cells: active regulators at the maternal-fetal interface. J Clin Invest 2014;124:1872-9.

46. Blois SM, Kammerer U, Alba Soto C, Tometten MC, Shaikly V, Barrientos G, et al. Dendritic cells: key to fetal tolerance? Biol Reprod 2007;77:590-8.

47. Moldenhauer LM, Diener KR, Thring DM, Brown MP, Hayball JD, Robertson SA. Cross-presentation of male seminal fluid antigens elicits $T$ cell activation to initiate the female immune response to pregnancy. J Immunol 2009;182:8080-93.

48. Plaks V, Birnberg T, Berkutzki T, Sela S, BenYashar A, Kalchenko V, et al. Uterine DCs are crucial for decidua formation during embryo implantation in mice. J Clin Invest 2008;118:3954-65.

49. Pollard JW. Trophic macrophages in development and disease. Nat Rev Immunol 2009;9:259-70.

50. Care AS, Diener KR, Jasper MJ, Brown HM, Ingman WV, Robertson SA. Macrophages regulate corpus luteum development during embryo implantation in mice. J Clin Invest 2013;123:3472-87.

51. Biswas SK, Mantovani A. Macrophage plasticity and interaction with Iymphocyte subsets: cancer as a paradigm. Nat Immunol 2010;11:889-96.

52. Van Ginderachter JA, Movahedi K, Hassanzadeh Ghassabeh G, 
Meerschaut S, Beschin A, Raes G, et al. Classical and alternative activation of mononuclear phagocytes: picking the best of both worlds for tumor promotion. Immunobiology 2006;211:487-501.

53. Guerin LR, Moldenhauer LM, Prins JR, Bromfield JJ, Hayball JD, Robertson SA. Seminal fluid regulates accumulation of FOXP3+ regulatory $T$ cells in the preimplantation mouse uterus through expanding the FOXP3+ cell pool and CCL19-mediated recruitment. Biol Reprod 2011;85:397-408.

54. Blois SM, Klapp BF, Barrientos G. Decidualization and angiogenesis in early pregnancy: unravelling the functions of DC and NK cells. J Reprod Immunol 2011;88:86-92.

55. Sacks G, Yang Y, Gowen E, Smith S, Fay L, Chapman M. Detailed analysis of peripheral blood natural killer cells in women with repeated IVF failure. Am J Reprod Immunol 2012;67:434-42.

56. Hsu P, Santner-Nanan B, Dahlstrom JE, Fadia M, Chandra A, Peek $M$, et al. Altered decidual DC-SIGN+ antigen-presenting cells and impaired regulatory T-cell induction in preeclampsia. Am J Pathol 2012;181:2149-60.

57. Gnainsky Y, Granot I, Aldo PB, Barash A, Or Y, Schechtman E, et al. Local injury of the endometrium induces an inflammatory response that promotes successful implantation. Fertil Steril 2010;94:2030-6.

58. Winger EE, Reed JL. Low circulating CD4(+) CD25(+) Foxp3(+) T regulatory cell levels predict miscarriage risk in newly pregnant women with a history of failure. Am J Reprod Immunol 2011; 66:320-8.

59. Whirledge SD, Oakley RH, Myers PH, Lydon JP, DeMayo F, Cidlowski JA. Uterine glucocorticoid receptors are critical for fertility in mice through control of embryo implantation and decidualization. Proc Natl Acad Sci U S A 2015;112:15166-71.

60. Chen Y, Wang Y, Zhuang Y, Zhou F, Huang L. Mifepristone increases the cytotoxicity of uterine natural killer cells by acting as a glucocorticoid antagonist via ERK activation. PLoS One 2012;7:e36413.

61. Quenby S, Kalumbi C, Bates M, Farquharson R, Vince G. Prednisolone reduces preconceptual endometrial natural killer cells in women with recurrent miscarriage. Fertil Steril 2005;84:980-4.

62. Andre S, Tough DF, Lacroix-Desmazes S, Kaveri SV, Bayry J. Surveillance of antigen-presenting cells by CD4+ CD25+ regulatory $T$ cells in autoimmunity: immunopathogenesis and therapeutic implications. Am J Pathol 2009;174:1575-87.

63. Franchimont D. Overview of the actions of glucocorticoids on the immune response: a good model to characterize new pathways of immunosuppression for new treatment strategies. Ann N Y Acad Sci 2004;1024:124-37.

64. Chen X, Oppenheim JJ, Winkler-Pickett RT, Ortaldo JR, Howard OM. Glucocorticoid amplifies IL-2-dependent expansion of functional FoxP3(+)CD4(+)CD25(+) T regulatory cells in vivo and en- hances their capacity to suppress EAE. Eur J Immunol 2006;36: 2139-49.

65. Cheloufi M, Kazhalawi A, Pinton A, Rahmati M, Chevrier L, Prat-Ellenberg $L$, et al. The endometrial immune profiling may positively affect the management of recurrent pregnancy loss. Front Immunol 2021;12:656701.

66. Hviid Saxtorph M, Persson G, Hallager T, Birch Petersen K, Eriksen JO, Larsen LG, et al. Are different markers of endometrial receptivity telling us different things about endometrial function? Am J Reprod Immunol 2020;84:e13323.

67. Smith MP, Mathur RS, Keay SD, Hall L, Hull MG, Jenkins JM. Periovulatory human oocytes, cumulus cells, and ovarian leukocytes express type 1 but not type 211 beta-hydroxysteroid dehydrogenase RNA. Fertil Steril 2000;73:825-30.

68. Casanueva FF, Burguera B, Muruais C, Dieguez C. Acute administration of corticoids: a new and peculiar stimulus of growth hormone secretion in man. J Clin Endocrinol Metab 1990;70:234-7.

69. Miell JP, Taylor AM, Jones J, Holly JM, Gaillard RC, Pralong FP, et al. The effects of dexamethasone treatment on immunoreactive and bioactive insulin-like growth factors (IGFs) and IGF-binding proteins in normal male volunteers. J Endocrinol 1993;136:525-33.

70. Michael AE. Life after liquorice: the link between cortisol and conception. Reprod Biomed Online 2003;7:683-90.

71. Kemeter P, Feichtinger W. Prednisolone supplementation to Clomid and/or gonadotrophin stimulation for in-vitro fertilization: a prospective randomized trial. Hum Reprod 1986;1:441-4.

72. Keay SD, Lenton EA, Cooke ID, Hull MG, Jenkins JM. Low-dose dexamethasone augments the ovarian response to exogenous gonadotrophins leading to a reduction in cycle cancellation rate in a standard IVF programme. Hum Reprod 2001;16:1861-5.

73. Liu S, Shi L, Wang T, Shi J. Effect of low-dose dexamethasone on patients with elevated early follicular phase progesterone level and pregnancy outcomes in IVF-ET treatment: a randomized controlled clinical trial. Clin Endocrinol (Oxf) 2018;89:771-8.

74. Boomsma CM, Keay SD, Macklon NS. Peri-implantation glucocorticoid administration for assisted reproductive technology cycles. Cochrane Database Syst Rev 2012;(6):CD005996.

75. Dan S, Wei W, Yichao S, Hongbo C, Shenmin Y, Jiaxiong W, et al. Effect of prednisolone administration on patients with unexplained recurrent miscarriage and in routine intracytoplasmic sperm injection: a meta-analysis. Am J Reprod Immunol 2015;74:89-97.

76. Kalampokas T, Pandian Z, Keay SD, Bhattacharya S. Glucocorticoid supplementation during ovarian stimulation for IVF or ICSI. Cochrane Database Syst Rev 2017;3:CD004752.

77. Achilli C, Duran-Retamal M, Saab W, Serhal P, Seshadri S. The role of immunotherapy in in vitro fertilization and recurrent pregnancy loss: a systematic review and meta-analysis. Fertil Steril 2018; 
110:1089-100.

78. Zhou G, Zhou M, Duan X, Li W. Glucocorticoid supplementation improves reproductive outcomes in infertile women with antithyroid autoimmunity undergoing ART: a meta-analysis. Medicine (Baltimore) 2021;100:e25554.

79. Geva E, Amit A, Lerner-Geva L, Yaron Y, Daniel Y, Schwartz T, et al. Prednisone and aspirin improve pregnancy rate in patients with reproductive failure and autoimmune antibodies: a prospective study. Am J Reprod Immunol 2000;43:36-40.

80. Revelli A, Casano S, Piane LD, Grassi G, Gennarelli G, Guidetti D, et al. A retrospective study on IVF outcome in euthyroid patients with anti-thyroid antibodies: effects of levothyroxine, acetyl-salicylic acid and prednisolone adjuvant treatments. Reprod Biol Endocrinol 2009;7:137.

81. Polak de Fried E, Blanco L, Lancuba S, Asch RH. Improvement of clinical pregnancy rate and implantation rate of in-vitro fertilization-embryo transfer patients by using methylprednisone. Hum Reprod 1993;8:393-5.

82. Ogasawara M, Aoki K. Successful uterine steroid therapy in a case with a history of ten miscarriages. Am J Reprod Immunol 2000; 44:253-5.

83. Quenby S, Farquharson R, Young M, Vince G. Successful pregnancy outcome following 19 consecutive miscarriages: case report. Hum Reprod 2003;18:2562-4.

84. Lee KA, Koo JJ, Yoon TK, Do BR, Ko JJ, Cha KY. Immunosuppression by corticosteroid has no effect on the pregnancy rate in routine in-vitro fertilization/embryo transfer patients. Hum Reprod 1994;9:1832-5.

85. Moffitt D, Queenan JT Jr, Veeck LL, Schoolcraft W, Miller CE, Muasher SJ. Low-dose glucocorticoids after in vitro fertilization and embryo transfer have no significant effect on pregnancy rate.
Fertil Steril 1995;63:571-7.

86. Ubaldi F, Rienzi L, Ferrero S, Anniballo R, lacobelli M, Cobellis L, et al. Low dose prednisolone administration in routine ICSI patients does not improve pregnancy and implantation rates. Hum Reprod 2002;17:1544-7.

87. Duvan Cl, Ozmen B, Satiroglu H, Atabekoglu CS, Berker B. Does addition of low-dose aspirin and/or steroid as a standard treatment in nonselected intracytoplasmic sperm injection cycles improve in vitro fertilization success?: a randomized, prospective, placebo-controlled study. J Assist Reprod Genet 2006;23:15-21.

88. Motteram C, Vollenhoven B, Hope N, Osianlis T, Rombauts LJ. Live birth rates after combined adjuvant therapy in IVF-ICSI cycles: a matched case-control study. Reprod Biomed Online 2015;30: $340-8$.

89. Seckl JR, Meaney MJ. Glucocorticoid programming. Ann N Y Acad Sci 2004; 1032:63-84.

90. Pinsky L, Digeorge AM. Cleft palate in the mouse: a teratogenic index of glucocorticoid potency. Science 1965;147:402-3.

91. Gur C, Diav-Citrin O, Shechtman S, Arnon J, Ornoy A. Pregnancy outcome after first trimester exposure to corticosteroids: a prospective controlled study. Reprod Toxicol 2004;18:93-101.

92. Laskin CA, Bombardier C, Hannah ME, Mandel FP, Ritchie JW, Farewell V, et al. Prednisone and aspirin in women with autoantibodies and unexplained recurrent fetal loss. N Engl J Med 1997;337: 148-53.

93. Carmichael SL, Shaw GM. Maternal corticosteroid use and risk of selected congenital anomalies. Am J Med Genet 1999;86:242-4.

94. Park-Wyllie L, Mazzotta P, Pastuszak A, Moretti ME, Beique L, Hunnisett $L$, et al. Birth defects after maternal exposure to corticosteroids: prospective cohort study and meta-analysis of epidemiological studies. Teratology 2000;62:385-92. 